\title{
Research on the Mode of Art Design Education for Freshmen in the Application-Oriented Universities
}

\author{
Pingqing Zhang \\ Arts Design Department \\ YanTai NanShan University \\ YanTai, LongKou, China \\ e-mail: hit_2007@163.com
}

\author{
Yang Wang \\ Arts Design Department \\ YanTai NanShan University \\ YanTai, LongKou, China \\ e-mail: nsxy2008@163.com
}

\begin{abstract}
It is suggested that the mode of Art Design education for freshmen in the application-oriented Universities, for example, "being teacher-centered", "being knowledgecentered" as well as "being book-centered", should be changed. Through this research, students majoring in arts design in the application-oriented universities can become a university teaching resources sharers, and can take advantage of the rich resources in research and practice, to improve the teaching quality of design education from the beginning of their university life.
\end{abstract}

Keywords-component; application-oriented university; freshman year; art design education; teaching mode

\section{INTRODUCTION}

Vocational education in the developed countries has formed a relatively complete system and has created different characteristics of the teaching mode. After 10 years' of practice and exploration, China's vocational education has formed a teaching mode suitable for our country. Research on the innovation of mode of Art Design education for freshmen in the application-oriented universities is conducive to deepening the reform of vocational education in the application-oriented universities and to further strengthen and improve the teaching mode to suit our country.

\section{GUIDING IDEOLOGY}

\section{A. With Clear Talent Cultivating Goals as the Basis to Structure the Teaching Mode for Freshmen in Art Design Education}

Higher Education in China has entered into a new stage of development with the application-oriented universities playing an important role in popularizing higher vocational education. Application-oriented universities should cultivate a special kind of talents who acquire good skills have the spirit of exploration, eager to solve the problem, have innovative thinking, and have rich practical experience. Those talent people are highly needed in the twenty-first century, which determines that thegoal of the applicationoriented universities should be the cultivation of high-quality skilled personnel.

\section{B. With Reallocation of Educational Resources to as the Foundation to Structure the Teaching Mode for Freshmen in Art Design Education}

After reconfiguring a variety of educational resources and reforming the curriculum of basic education, the freshmen in the application-oriented universities can share superior resources through various forms and obtain a variety of educational experiences and skills. Besides, heir professional skills can be supplemented. . Such measures can ensure that students can take advantage of technical, intellectual and cultural resources provided in the school, the surrounding community as well as the surrounding industrial park.

\section{With the Reconstructive Curriculum System as the Precondition to Structure the Teaching Mode for Freshmen in Art Design Education}

\section{1) The curriculum structure reform}

Since the educational concepts which drive innovation and reform in curriculum system update, reasonable course structure is built as the basic content of social sciences, natural sciences and humanities, and as the core curriculum for skills training and experiment training.

\section{2) Interdisciplinary education}

Interdisciplinary curriculum should account for more than $50 \%$ of lesson plans. There are three main types of interdisciplinary curriculum. They are, traditional culturebased curriculum, problem-based curriculum, and skillsbased curriculum. Students should complete all those Core Curriculums. On this basis, setting selective courses among departments is to expand their horizons, improve their basic skills, as well as expand employment-oriented.

\section{3) Practical teaching}

Application-oriented universities should generally establish links with the industry, business and the business communities. Besides, they should actively promote schoolenterprise cooperation and encourage students of low-grade to enter into the business to make practices. It's quite a good chance for their development through practice in a real environment. 
D. With the Reform of Teaching Methods as the Guarantee to Structure the Teaching Mode for Freshmen in Art Design Education

Reform of teaching methods and means of education will directly affect the implementation and operation for the teaching mode for freshmen year. Therefore, when building a new model, we should make efforts to select the most suitable teaching methods and means of education as well as combine the traditional and modern teaching methods and approaches.

\section{CONSTRUCTING APPLICATION-ORIENTED AND} SKILLED TEACHING MODE FOR FRESHMEN IN ART DESIGN EDUCATION

\section{A. Raise of the Concept}

Practical teaching is a teaching method that cultivates students with the basic skills necessary for practitioner's posts and that improves students' ability to solve practical problems. Through practical teaching, pupils can develop a good ideological quality and professional ethics. They can also combine the study of professional skills and the experience gained in their corporate internships under the teacher's guidance. Practical teaching mode is a methodology that refers to creating a learning environment in the process of implementation of practical teaching. It also refers to the teaching content which involves methods of selection and the setting of curriculum in order to achieve the expected goal.

\section{B. Design Principles}

The principles constituting the teaching mode for freshmen in art design education includes "student-centered" principle, "Problem-pilot" principle, "task-driven" principle, "to the freshman year as a starting point" principle, "application-oriented and skilled "principles.

\section{1) Student-centered}

Students should shift from passive learning (understand and accept the knowledge passively) to self-learning (explore and practice what they've learnt in the practical teaching). Teachers are no longer "a sage on the stage" instead they should play the role of "off-coach". Teachers should impart to the students not only the knowledge they have, but also their precious experience. When designing the teaching process, teachers should be student-centered. They ought to provide students with both teaching resources and suggestions on learning. Teachers should focus on inspiring, motivating, guiding students from the practical aspects and timely evaluate the effect of their teaching.

\section{2) Problem-pilot}

The learning process of students does not explain the basic principles and concepts, but begins from the practical problems. Students need to collect and collate relevant information by themselves or in teams, and ask questions and figure out solutions. Students need to evaluate the question and the model adopted. Students should learn and master the curriculum and other related knowledge through the process of research and practice.

\section{3) Task-driven}

The teachers should not provide students with readymade materials. Instead, they should use practical training to teach students how to learn and ask question so that students can explore and practice with questions. In such way, students can acquire more and be more innovative and active.

\section{4) Freshman year as a starting point}

If we take the four years of undergraduate education as a whole, the first year is the cornerstone of this whole process. There is a proverb which says "The whole year's work depends on a good start in spring". That is to say, the first year of teaching to higher education what seed-sowing is to agriculture. The first fundamental question of freshman year is to build a foundation for professional curriculum framework; the second is to set a basic course which can lay the foundation for specialized courses; the third is to operate in order to achieve the purpose of the foundation.

5) Application and skills as the goal of talents training

The training objective of Application-oriented university is to make students apply the advanced technology.. Students are the lifeblood of university's education and development. Application-oriented university pays attention not only to strengthening the basic theory of education, but also to highlighting the practical aspects of education. Applicationoriented university trains students to have a wide range of knowledge and skills through the combination of theoretical knowledge and practical, as well as the combination of classroom knowledge and social ability. Application-oriented university provides a platform to fully display the learning effects and the courage to practice.

\section{YANTAI NANSHAN UNIVERSITY AS AN EXAMPLE TO FOCUS ON STRENGTHENING THE APPLICATION-ORIENTED AND SKILLED TEACHING MODE FOR FRESHMENN IN ART DESIGN EDUCATION}

\section{A. Participating in Training, Freshman at the Application- Oriented University Share the Laboratory Resources}

As the application-oriented universities take the training of applied talents as their goals, the freshmen should contact with the laboratory resources and partake of the design training. Yantai Nanshan University will utilize the school's hardware resources to organize students to participate in the experiment and practical training of professional courses through tours, internships and other forms of activity. In this way, the freshmen will have a perceptual awareness for the expertise required, which will lay a good foundation for further education and career planning.

\section{B. The School-Enterprise Cooperation Strengthened and Promoteed the Incorporation of the Class Teaching and the Design Practice}

Yantai Nanshan University set up a professional curriculum according to the business needs, and vigorously trains highly skilled design talents for the business needs.

Yantai Nanshan University and Nanshan Group worked closely on the school-enterprise cooperation. Nanshan Group has developed into a large-scale private joint-stock enterprise which includes three parks, 20 residential areas and nearly 60 
companies. Nanshan Group engages in fields of aluminum, textile and apparel, finance, real-estate, tourism and other leading industries. Nanshan Group provides a broad space of internships and employment for student, which ensures the effective convergence in classroom teaching and production practices.

Taking Art and Design Department of Yantai Nanshan University as an example, the teachers of Environmental Design Department actively organized production practice for students to take part in Nanshan furniture factory, which not only will make them further understand the knowledge learned in the classroom, but also will deepen their expertise in the design practice. It is greatly beneficial to improve the students' ability to solve practical problems. At the same time, the Department of Art and Design will strengthen the schoolenterprise cooperation with Nanshan furniture factory, Nanshan decoration companies, the advertising department of Nanshan Group, Nanshan Institute of Architectural Design and Nanshan Real Estate, which will create more opportunities for students get internships and employment and to practice what they've learnt.

\section{CONCLUSION}

The teaching mode for freshmen at application-oriented universities has always focused on applied training on the search for new knowledge so that students can apply what they have learned to solve practical problems. This can stimulate students' enthusiasm for learning as well as their initiative. Practice teaching in the freshman year should also be an important part of education in application-oriented universities according to China's national conditions. As a new teaching mode, it provides students with more experience and develops their creativity and practical ability. Under such teaching mode, students can master the techniques and methods in their own field as well as get ready for their future career.

\section{REFERENCES}

[1] Jianqun Lin. Research On The Teaching Mode Of Research Universities In The Freshman Year[Z]. Chinese Association of higher education "fifteen" of higher education and scientific research. 2005.12

[2] Pingqing Zhang,YangWang. Research on interest and accepting psychology of college freshman year in art design education[Z]. International Conference on Education, Language, Art and Intercultural Communication (ICELAIC 2014), 2014.05

[3] HuaLiang. The innovative necessity and realization path of Art and Design teaching mode[J]. Modern Enterprise Education, 2014.01

[4] Pingqing Zhang,YangWang.the mode of teaching practicality on the freshman in the college which run by the local peaple[J]. Journal of Beijing City University, 2012.01

[5] Qianyi Lin.study on the experience program of american freshman[D]. East China Normal University, 2008.04

[6] LinHong.practice teaching and base construction of the application oriented university in foreign countries[J].Research and Exploration in Laboratory, 2006.12

[7] Yingjun Xu.the features and the development path of the application oriented university[J]. Higher Education Research \& Evatuation, 2007.03 